Revista Iberoamericana, Vol. LXXIII, Núm. 218, enero-marzo 2007, 79-92

\title{
PRAGMATISMO Y EL DISCURSO INGENIOSO EN EL SERMÓN DE LA EPIFANÍA DEL PADRE ANTONIO VIEIRA
}

POR

Nicole Caso

Bard College

Después de la expulsión de los misioneros jesuitas del Maranhão en 1661, el padre Antonio Vieira predica el Sermón de la Epifanía en 1662 en la Capela Real de Lisboa ante los reyes de Portugal. ${ }^{1}$ Su propósito principal es exponer la necesidad de preservar las misiones jesuitas en la Amazonia brasileña y promover la empresa evangelizadora. En juego está el control no sólo sobre las almas de los indígenas brasileños, sino también sobre sus cuerpos. Según él lo expone, el padre Vieira busca más que el derecho de convertir a los indios paganos: quiere asegurarse además de que podrá proteger a los indígenas convertidos ante los abusos de los colonos portugueses.

Si bien se ha estudiado el Sermón de la Epifanía en torno a su contexto histórico -Thomas Cohen opina que es el sermón más importante que Vieira predicó sobre la sociedad brasileña- este ensayo propone analizar la conexión entre la retórica barroca del texto y el contenido ideológico, político y religioso. Una de las preguntas centrales que organiza mi acercamiento al texto de Vieira es ¿qué forma toma el lenguaje en un momento de crisis tanto política (la expulsión de los jesuitas) como conceptual (la incómoda ausencia de América en las profecías de la Biblia)? Ultimadamente, las ingeniosas estrategias retóricas del padre Vieira le sirven para intervenir en la política de Portugal en la Amazonia y para intentar resolver las múltiples tensiones inherentes entre su experiencia empírica en las misiones brasileñas y el contenido literal del texto bíblico que rige su profesión.

Tanto en Brasil como en Portugal el padre jesuita logró acumular múltiples enemigos. Su proyecto teológico e ideológico -expresado por medio de sus sermones públicos- se encontró con virulentos oponentes no sólo ante los colonos, sino también ante los religiosos de otras órdenes católicas. Entre sus ideas más controversiales figuran: su defensa de los indios, de los judíos y los conversos, y su propuesta política de venderles a los holandeses Pernambuco, en Brasil. ${ }^{2}$ Eventualmente, Vieira sería llevado al tribunal de la Santa Inquisición por sus ideas consideradas tan heréticas.

${ }^{1}$ La rúbrica del sermonario indica que el sermón fue predicado ante D. Luísa y el joven D. Alfonso VI, antes de que éste asumiera sus responsabilidades oficiales por ser menor de edad.

${ }^{2}$ En el llamado Papel Forte, el padre se ingenió un plan bajo el cual se vendería Pernambuco para poder ganar tiempo en las disputas contra Holanda y poder reconquistar esta región subsecuentemente. El resultado de su propuesta fue que los colonos lo acusaron en 1648 de traicionar a Brasil (Rabassa 177). 
En cuanto a su defensa de los indígenas, el padre Vieira indica en el Sermón de la Epifanía que acepta la institución de la esclavitud, pero sólo en el caso de una "guerra justa” (Rabassa 180): “Não é minha tenção que não haja escravos [...] nós queremos que tenham escravos, mas sem demonio [...]” (Sermões 238-239). Cohen explica la trayectoria de las ideas de Vieira en torno a la esclavitud de los indígenas:

[...] Vieira had begun his work in the Amazon with the expectation that the missionary church would find a way to coexist with the institution of slavery. Now [in the Epiphany sermon] Vieira declares that the two are irreducibly opposed, not because of slavery's inherent evils but because of human greed. (Cohen 115)

[Vieira había empezado su labor en la Amazonia con la expectativa que las misiones podrían encontrar una manera de coexistir con la institución de la esclavitud. Ahora [en el Sermón de la Epifanía] Vieira declara que las dos se oponen irreduciblemente, no por las maldades inherentes en la esclavitud sino por la codicia humana.] (traducción mía)

Anteriormente, Vieira le había recomendado al rey que las expediciones, llamadas entradas, que llevaban a cabo los colonos capturando grupos de indígenas en la jungla y el sertão se dejaran exclusivamente en manos de los religiosos que fueran de la misma orden de aquellos que administraran los pueblos, dándole así unidad al proyecto de convertir a los nativos en fieles súbditos cristianos (Rabassa 180). Claramente, este esquema de poder sobre la colonización de los indígenas les resultaba problemático a los colonos seculares que dependían de la fuerza laboral de los nativos para llevar a cabo sus propias empresas en el Nuevo Mundo.

Asimismo, puesto que los colonos requerían la labor de los indígenas, y dado el hecho que en diversos momentos fueron los jesuitas mismos quienes tenían el poder de distribuir a los trabajadores indígenas en la región de la Amazonia, la tensión entre jesuitas y colonos europeos llegó a tal punto que culminó con la expulsión de los misioneros de la región en $1661 .{ }^{4}$ En un viaje a Lisboa unos años antes, el padre Vieira había logrado que en abril de 1655 el rey de Portugal promulgara una ley que demarcaba el proceso de procurar trabajadores indígenas y les daba el derecho exclusivo a los jesuitas de llevar a cabo las labores misioneras entre los indios del Maranhão. Dada esta concentración de autoridad sobre la comunidad indígena en las misiones jesuitas, Vieira se tuvo que encarar con múltiples enemigos cuando regresó a Brasil. Es más, después de la muerte de su protector João IV $^{5}$ en 1656, y después de la partida de André Vidal de Negreiros, gobernador de Maranhão, los colonos portugueses se tornaron más abiertamente en contra del padre y sus colegas jesuitas, logrando su eventual expulsión de la zona.

\footnotetext{
${ }^{3}$ Todas las traducciones son mías a menos de que indique lo contrario.

${ }^{4}$ Para un panorama detallado sobre las negociaciones de poder entre colonos y jesuitas en la región, ver el libro de Thomas M. Cohen, The Fire of Tongues: António Vieira and the Missionary Church in Brazil and Portugal.

${ }^{5}$ El padre Vieira había sido un consejero y aliado personal del rey João IV a partir de la década de los años 1640 hasta su llegada a Maranhão en 1653. Desempeñó el cargo de predicador de la corte de Lisboa, fue el confesor y tutor del hijo del rey, el Príncipe Teodósio, y fue el embajador personal para el rey en Francia y Holanda en 1646 y 1647 (Rabassa 177-78).
} 
Al ver que los colonos habían logrado interrumpir las labores de los misioneros -que para Vieira figuraban centralmente en la preparación de su visión milenaria del llamado Quinto Imperio- el padre recurre a sus sermones para tratar de intervenir en la situación política. ${ }^{6}$ Si bien al principio de su llegada a las misiones del Maranhão Vieira trata de manejar con cautela y diplomacia las tensiones entre sus responsabilidades de predicarles a los portugueses de la colonia y las de convertir a los paganos de la región, ya para 1661 le queda claro al padre jesuita que su prioridad es más bien la segunda. De tal manera que, en una situación bastante precaria para Vieira, el Sermón de la Epifanía tiene motivaciones altamente políticas - nada menos que el convencer a los reyes de Portugal (presentes ambos en el público de la Capela Real) que les devolviera la autoridad a los jesuitas sobre los indígenas del Maranhão para poder llevar a cabo sus misiones evangelizadoras y preparar el camino para la llegada del Quinto Imperio.

Al considerarlo como figura altamente polémica, otro factor que seguramente añadía a su carácter controversial en ciertos círculos es el de su descendencia familiar.

Además de su innegable descendencia africana -su abuelo se había casado con una mujer mulata- algunos biógrafos han defendido la noción de que Vieira tenía también sangre judía. ${ }^{7}$ Desde la perspectiva de sus coetáneos estos factores raciales seguramente hubieran sido una consideración significativa dada la importancia de la "limpieza de sangre” en la península ibérica del siglo xVII. Estas consideraciones hubieran podido afectar no sólo la opinión de otros en cuanto a la recepción de los argumentos predicados por el padre, sino también, más interesantemente, podrían haber influido directamente en la formación de su propia ideología personal.

En un pasaje muy sugerente del Sermón de la Epifanía Vieira expone la lógica cuestionable que justifica lo que hoy día se denominaría el racismo occidental. Después de señalar que los colonos suelen decir que sus esclavos han de ser esclavos simplemente porque son “negros”, el padre invierte esta lógica para que el más prieto de la comparación sea efectivamente el portugués:

Já considerei algumas vezes porque permittiu a Divina Porvidencia ou ordenou a Divina Justiça, que aquellas terras e outras vizinhas fôssem dominadas dos herejes do Norte. E a razão me parece que é porque nós sômos tão pretos em respeito d'elles, como os Indios em respeito de nós; e era justo que pois fizemos taes leis, por ellas se executasse em nós castigo. Como se dissera Deus, já que vós fazeis captivos a estes porque sois mais brancos que elles, eu vos farei captivos de outros que sejam, também, mais brancos que vós. (Sermões 237, énfasis mío)

\footnotetext{
${ }^{6}$ Ver los capítulos de Thomas Cohen, "Visions of the Portuguese Empire” y “The Ignatian Mission Renewed”, para mayor información sobre los pormenores del Quinto Imperio bajo la corona portuguesa, según lo concebía el padre Vieira. El ensayo de Silvano Peloso en la compilación Vieira escritor también trata sobre este tema.

${ }^{7}$ Jamil Almansur Haddad nota esta posibilidad en la introducción que escribe en 1954 a Sermões: "Este espírito messiânico a certa hora poderia ter sido explicado por judaismo. Dizia-se no Maranhão que Vieira havia sido batizado em pé (54) [...] Quanto à raça, o sangue negro em Vieira é certo. O judaico, simplesmente provável” (70).
} 
Los "herejes del norte" ostensiblemente son los holandeses; y si los portugueses han decidido subyugar a los indígenas basados en el color de su tez, pues sería la Justicia Divina la que ordenaría la invasión holandesa en tierras portuguesas en el Nuevo Mundo en una suerte de venganza equitativa bajo los parámetros establecidos por sus propios compatriotas. Esta inversión está cargada de una ironía que atenta contra la legitimidad del argumento a favor de la problemática de la esclavitud indígena en su fundamento. Vieira hace hincapié en el hecho de que la "ley" que dicta que la oscuridad de la piel equivale a la sumisión bajo otros más blancos es una ley hecha por los hombres, no por un orden divino o natural: "era justo que puesto que [nosotros] hicimos tales leyes, por ellas se ejecutara en nosotros el castigo”.

El padre Vieira insiste en desestabilizar la justificación de los colonos con un lúcido ejemplo del evangelio en el cual Salomón demuestra la "gran sinrazón de esta injusticia" al presentar a la mujer de Moisés (de Etiopía), que fue despreciada por las mujeres de Jerusalén. ${ }^{8} \mathrm{Al}$ considerar en este ejemplo la arbitrariedad de la causa de la diferencia del color de la piel, y declarar que la única diferencia entre la mujer de Etiopía y las de Jerusalén es cuán lejos o cerca del sol nacieron, la lógica de los colonos se trivializa y, al replantearse, parece perder sentido. ¿Cómo es posible que un hombre o una mujer impongan su poder sobre el otro basado en su distancia del sol en el momento de su nacimiento? Se desestabiliza así el argumento en pro de la esclavitud por razones fisonómicas. La procedencia de sus propios antepasados sin duda tuvo algún impacto en su perspectiva tan abierta en cuanto a las causas y las justificaciones del racismo occidental.

Antes de profundizar en el texto del Sermón de la Epifanía, nos detendremos un momento para considerar el uso y la función del género del sermón en Portugal durante el siglo xvir. Margarida Vieira Mendes escribe sobre este tema en A oratória barroca de Vieira (1989) y propone que:

A pregação exerceria em Portugal um papel semelhante ao do teatro espanhol no Siglo de Oro que, segundo J. António Maravall (1972), funcionou como agente da política real, da produção e reprodução ideológica, e da formação da opinião. As restrições e proibições relativas aos espectáculos de teatro profano em Portugal, em parte obtidas pelos jesuítas, e a ausência de teatro na corte proporcionaram à pregação uma área de influência maior, além de a predisporem para um acréscimo de teatralidade, na utilização substitutiva de certos meios comuns a ambas expressões. (Vieira Mendes 78)

Según esta aseveración, la predicación en el púlpito religioso tenía dimensiones de adoctrinamiento político e ideológico -generalmente aquel impuesto por la autoridad

\footnotetext{
8 “[...] a Ethiopiza, mulher de Moysés, que era preta, fallando com as senhoras de Jerusalém, que eram brancas, e por isso a desprezavam [...] diz assim: [...] se me desestimaes porque sois brancas, e eu preta, não considereis a côr, considerae a causa: considerae que a causa d'esta côr é o sol, e logo vereis quão inconsideradamente julgaes. As nações, umas são mais brancas, outras mais pretas, porque umas estão mais vizinhas, outras mais remotas do sol. E [não] pode haver (sic.) maior inconsideração do entendimento, nem maior erro do juizo entre homens, que cuidar eu que hei-de ser vosso senhor, porque nasci mais longe do sol, e que vós haveis de ser meu escravo, por que nascestes mais perto?!” (Sermões 237-8).
} 
monárquica- y también suplía un espacio de carencia debido a las estrictas restricciones sobre el teatro profano. De esta forma, el sermón era tanto pragmático, por un lado, como un espectáculo teatral que ayudaba a entretener al público a la vez de persuadirlo. "Na cultura barroca passam a dominar factores de persuasão, de propaganda, de atracção do indivíduo à ordem social. A pregação em Portugal seria um meio de penetração nas consciências e do controlo psicológico, uma aposta na capacidade transformadora da acção humana” (Vieira Mendes 78). Si bien gran parte de los sermones en Portugal, e incluso los de Vieira, se utilizaban de la manera en que Maravall describe que se usaba el teatro español en el Siglo de Oro -para imponer y reforzar la autoridad de la monarquíaen el Sermón de la Epifanía Vieira predica desde una posición relativamente marginal, puesto que recién ha sido expulsado de su misión en Maranhão. Su motivo ulterior es convencer a los monarcas portugueses que le devuelvan el poder que ha perdido, para proteger a los indígenas brasileños y ultimadamente preparar el camino para la llegada del Quinto Imperio. ${ }^{9}$ A quien necesita impactar psicológicamente y persuadir es precisamente a los reyes.

Mencionando directamente su rol de predicador, Vieira empieza el Sermón de la Epifanía con una inversión sorprendente. En lugar de desempeñar su función tradicional como predicador -el de la interpretación del Evangelio- el padre jesuita dice que va a recurrir al Evangelio para que éste explique la función del predicador en sí: “[...] será hoje, o Evangelho o prègador. Esta é a novidade que trago do Mundo Novo. O estylo era que o prègador explicasse o Evangelho: hoje o Evangelho ha-de ser a explicação do prègador. Não sou eu o que hei-de commentar o Texto; o Texto é o que me ha-de commentar a mim" (Sermões 205, énfasis mío). Será el Texto que lo comentará a él. El padre Vieira se basa en la supuesta voluntad de Dios, escrita en el Evangelio, para autorizar su propio argumento. El autor construye un discurso conceptista y deslumbrante con una finalidad altamente pragmática para la defensa de los indígenas, del proyecto jesuita, y de su propio estatus de poder. Vieira quiere convencer a su público en la Capela Real sobre la legitimidad de la misión jesuita en Brasil y simultáneamente logra enaltecer la labor del predicador en sí.

El sermón está estructurado según los siguientes temas: I. La equiparación de la epifanía bíblica con la conversión de los indígenas y del nacimiento de Cristo con el nacimiento del cristianismo. II. El resultado paradójico del éxito de la conversión de los indígenas: los colonos cristianos persiguen a los predicadores de la fe y los gentiles indios

\footnotetext{
${ }^{9}$ Cabe recordar que la razón por la cual Vieira pierde su poder y es vilipendiado por los colonos es precisamente por su empeño en defender los derechos de los indígenas. Sin embargo, su manera de defenderlos requiere mantenerlos bajo la autoridad de los jesuitas y esto hace que su postura ante los indígenas sea bastante ambivalente según nuestra perspectiva actual. Luís Palacin escribe sobre las críticas que le hace el padre Vieira al sistema colonial, particularmente sobre "la imposibilidad de cualquier gobierno bueno y justo en las colonias, la apropiación de sus riquezas por parte del Reino, y la fuerza y violencia inherente al sistema” (20). También argumenta Palacin que a pesar de que Vieira haya estado "decididamente del lado de la autoridad, y por consiguiente del empleo de la fuerza como un medio de obligar al bien", "esto no le impedía elevarse hasta la grandeza en la defensa del derecho de los oprimidos como los indios y los cristianos nuevos, enfrentándose al destierro y la cárcel” (Palacin 29).
} 
los adoran. III. Una explicación detallada de por qué los indios adoran a los predicadores. IV. La presentación del argumento de los colonos, para contrarrestarlo. V. El "remedio" que propone para mejorar la presente situación.

Una de las paradojas centrales del texto es la pregunta que se hace el jesuita al principio del sermón: Si el Evangelio dice que los tres Reyes Magos que vinieron a adorar al niño Jesús representaban a todas las partes del mundo ¿por qué sólo llegaron reyes de Asia, África y Europa? El dilema del padre es sobre cómo reconciliar la versión de la historia representada en la tradición bíblica con una nueva realidad empírica: la existencia de todo un continente lleno de "paganos" que aún no han recibido la palabra de Dios cuando la Biblia especifica que toda la gente del mundo había de adorar a Cristo. Vieira necesita ajustar sincréticamente a ambas representaciones del pasado, sin desechar a ninguna de las dos. Siendo hombre de la Iglesia, obviamente no puede negar las palabras del Evangelio, pero a la vez está viviendo una realidad física que no está prevista en el texto al que debe referirse.

El problema es análogo al cambio de paradigmas que se estaba dando en el campo de la astronomía descrito por Fernand Hallyn en "Thinking the Ellipse” (1990). Hallyn escribe que el reemplazo del círculo por la elipse -refiriéndose al movimiento de los planetas-que introdujo Kepler con sus descubrimientos empíricos no se lleva a cabo bajo un deseo por cambiar las nociones de "circularidad”. Muy al contrario, Kepler se encara con las pruebas empíricas de la elipse partiendo de una creencia en la perfección estética del círculo - una noción apoyada por la Iglesia. Hallyn describe este proceso al comentar sobre la publicación de la primera ley de Kepler en Astronomia nova (1609):

Such a procedure vindicates the conclusions of Astronomia nova: the reader will see that they do not arise from a desire to put an end to the dogma of circularity or to innovate at any cost, but on the contrary, from an odyssey undertaken under the very sign of the prevailing belief in the circle [...] The ellipse is a constraint, not a choice. (Hallyn 205) [Tal procedimiento reivindica las conclusiones de Astronomia nova: el lector verá que no resultan de un deseo de ponerle fin al dogma de la circularidad o de innovar a cualquier costo, sino al contrario, de una odisea llevada a cabo bajo el mismo signo de la creencia prevaleciente en el círculo [...] La elipse es una restricción, no una elección.]

De esta forma, lo ideal entra en una tensión dinámica con lo material, desfigurando el círculo perfecto para convertirlo en una nueva figura que incluye y, de hecho, se fundamenta en las tensiones que resultan de insistir en cierta continuidad con el pasado. El círculo todavía se percibe, distorsionado, en la estética de la elipse. ${ }^{10}$

Analógicamente, bajo la fe en el Evangelio (equiparable con el círculo, lo ideal) Vieira se ve forzado a explicar la realidad empírica que vive (la América "pagana”, lo material) en un ámbito de severa restricción. El resultado es la creación de una serie de conceptos e imágenes deslumbrantes, llenos de tensión inherente, que se pueden equiparar a la elipse kepleriana. La comparación se basa sobre todo en la tensión entre la ideología

${ }^{10}$ Ver también el ensayo de Severo Sarduy, titulado "Barroco”, para un detallado análisis de la relación entre los cambios paradigmáticos en la cosmología de la época y la estética barroca, texto en el cual afirma Sarduy que "el del barroco es el espacio de Kepler" (1222). 
del punto de partida de Kepler y Vieira, y las realidades empíricas que la distorsionan. De pronto, surge una necesidad de incluir los dos focos de la elipse, en lugar de referirse al centro único y estable que provee el círculo. Como veremos abajo, Vieira recurre a la figura retórica del concepto barroco y las comparaciones ingeniosas para unir dos términos aparentemente contradictorios, incluyendo así en un mismo plano tanto lo material como lo ideal.

Vieira resuelve sagazmente la omisión de América en la llegada de los Reyes Magos proponiendo que no es sólo una sino que son dos epifanías las que están profetizadas en la Biblia: una en los días de Herodes, la otra en la época contemporánea al sermón. Las dos epifanías se convierten así en los dos focos de una elipse simbólica, que empujan y distorsionan la perfecta "circularidad" del Texto previo a las complicaciones empíricas. Se evidencia el grado de tensión que exige la creación de dos focos en las palabras de Vieira:

Estas são as primeiras palavras do Evangelho, e logo n'ellas parece que repugna o mesmo Evangelho a ser meu interprete, porque a sua historia e o seu mysterio é da India Oriental [...] e o meu caso é das Occidentales. Se appelo para os Reis e para o sentido mystico, tambem está contra mim, porque totalmente exclue a América, que é a parte do mundo, d’onde eu venho. (Sermões 206, énfasis mío)

El Evangelio que se supone que lo va a comentar a él como predicador, lo rechaza y lo excluye. Por eso tiene que "releer" el Texto para encontrar en él un sentido que lo incluya. El texto bíblico queda tan distorsionado en el proceso que en realidad es él mismo quien crea tal término inclusivo al final.

Tanto el Viejo como el Nuevo Testamento presagiaron la llegada de los reyes del Oriente y los de Occidente, pero sólo llegaron los de Oriente al nacimiento de Jesús. Esto le indica a Vieira que en algún momento subsiguiente tendrían que llegar los de Occidente a adorar a Cristo. En su opinión, estos serían los portugueses. Los tres reyes de Occidente -que dijo S. Bernardo que predicarían la fe que Cristo les predicó a los tres reyes de Oriente- los identifica Vieira como los tres reyes de Portugal que "comenzaron", “prosiguieron”, y “perfeccionaron” el descubrimiento del Nuevo Mundo: D. João II, D. Manuel, D. João III. Gracias a ellos se lleva la fe cristiana a Asia, África y América. Vieira considera que esta misión evangelizadora está descrita también en el pasaje de la Biblia en que Dios promete crear un nuevo cielo y una nueva tierra, en el Apocalipsis de San Juan. Vieira no interpreta esta promesa como un paraíso después de la muerte, sino que toma las palabras de Dios literalmente: el nuevo mundo prometido por Dios son las tierras y los cielos del mundo nuevo descubierto por los portugueses:

Pois essa é a terra nova e esses são os céos novos que Deus tinha promettido, que havia de crear, não porque não estivessem já creados desde o principio do mundo, mas porque era este o Mundo Novo tão occulto e ignorado dentro no mesmo mundo, que quando de repente se descobriu e appareceu, foi como se então começára a ser, e Deus o creára de novo. (Sermões 209, énfasis mío) 
El mundo nuevo sólo era “nuevo” porque aún no lo habían “descubierto” los del Occidente. Al igual que la elipse Kepleriana, el mundo nuevo ya existía pero estaba “oculto e ignorado"; les era desconocido a los que moraban en el Mundo Viejo. Vieira demuestra cómo el descubrimiento del Nuevo Mundo necesariamente cambia al Mundo Viejo recurriendo a las palabras del Apocalipsis de San Juan:

[...] á vista d'este céo novo, e d'esta terra nova, o céo e a terra antiga desappareceram, e que o mar já não era [...] assim aconteceu no descobrimento do Novo Mundo. Desappareceu a terra antiga, porque a terra d'alli por diante já não era a que tinha sido, senão outra muito maior, muito mais estendida e dilatada em novas costas [...] em novas regiões, em novas gentes, em novos animaes, em novas plantas. Da mesma maneira o céo tambem começou a ser outro [...]

Sobretudo o mar que fôra, já não é [...]. (Sermões 210)

Ya nada podría ser igual que antes con el descubrimiento del resto del mundo existente. El Apocalipsis del Mundo Viejo trae consigo la renovación y la creación de un Mundo Nuevo. La implicación que conllevaba, según Vieira, era un llamado a fundar una nueva Iglesia. Esta misión la llevarían a cabo los portugueses: "Porque havendo Deus creado o mundo na primeira creação por si só, e sem ajuda ou concurso de causas segundas, n'esta segunda creação tomou por instrumento d'ella os Portuguezes, quasi pela mesma ordem, e com as mesmas circumstancias, com que no principio tinha creado o mundo". (Sermões

Curiosamente, el padre jesuita ignora a Colón y a los conquistadores españoles cuando propone que recaería sobre los portugueses el sacar al nuevo mundo de la oscuridad y las tinieblas en que se encontraba antes de su llegada. Vieira equipara la empresa de los portugueses al génesis, y con su retórica carismática los convierte, de cierta manera, en los creadores del nuevo mundo, los regidores del Quinto Imperio. En todo este pasaje del sermón, Vieira encadena una serie de conceptos e imágenes que logra relacionar por medio de comparaciones y oposiciones ingeniosas: citas e interpretaciones del Apocalipsis y el Génesis, imágenes de oscuridad, tinieblas y de luminosidad, de infidelidad e ignorancia y conocimiento de Cristo. El efecto deseado es arribar a la conclusión de que si los portugueses son los “creadores” de la nueva Jerusalén, los jesuitas son las “estrellas” que deben llevarle la luz a los impíos.

Mientras que el Sermón de la Epifanía tiene una finalidad pragmática y concreta, el tipo de discurso que utiliza no es uno basado en la razón empírica. Su calidad carismática recae más bien en lo que Saraiva llama su "discurso ingenioso", refiriéndose a la Agudeza y arte de ingenio (1648) de Baltasar Gracián:

[...] só o discurso engenhoso, na medida em que quebra as palavras e seu encadeamento habitual, possibilita a expressão de crenças, sonhos, intuições que se situam fora da razão. Por outro lado, se o discurso engenhoso não pretende convencer pelo raciocínio, é o único capaz de despertar a imaginação e condicionar o espíritu pelos métodos da surpresa e dos vínculos intangíveis e incontroláveis, verdadeiros ou falsos, que as palavras estabelecem entre conceitos diferentes. (Saraiva 122) 
Saraiva subraya el hecho de que en el arte de convencer a su público Vieira no recurre a argumentos empíricos, racionales, sino que más bien apela a la imaginación. El control psicológico del que escriben Maravall y Vieira Mendes, que se obtiene a través de la teatralidad, se logra "quebrando las palabras y su encadenamiento habitual”. Es decir, Vieira crea un discurso en el que por medio de comparaciones analógicas y oposiciones inesperadas captura la imaginación de sus oyentes y los lleva de un concepto a otro hasta llegar a una conclusión que deriva su "verdad” de la destreza retórica del predicador. Hasta cierto punto, no importa tanto el contenido de las palabras que dice; lo que importa es el efecto que producen para poder hacer que sus oyentes se comporten de la manera que él pretende. ${ }^{11}$ Saraiva compara este proceso con los esloganes de la propaganda moderna (122). En los sermones de Vieira, el “concepto” de Gracián deja de ser meramente una construcción artificiosa que aspira a la hermosura. ${ }^{12}$ La hermosura estética del concepto adquiere funciones bastante pragmáticas para el predicador.

Los conceptos sensoriales de la luz y la oscuridad, ligados a la fe cristiana, por ejemplo, le sirven al padre Vieira para hilvanar una serie de conexiones que conducirán desde el descubrimiento del Nuevo Mundo hasta la presente situación de crisis en Brasil. Primero, el "Nuevo" Mundo, ya existente, está escondido entre las tinieblas y el desconocimiento de Cristo; luego llegan los portugueses y traen la luz y la fe. Irónicamente, como resultado del éxito de esta empresa, los colonos vuelven a sumir a las tierras descubiertas en las tinieblas al expulsar a los jesuitas de sus misiones. Como parte del performance, el predicador define bien claramente quiénes son los protagonistas de su obra. En una analogía inesperada, que llega hasta los límites de la blasfemia en su atrevimiento, Vieira equipara a los misioneros jesuitas con Cristo, jestableciendo en esencia que la labor de los jesuitas se podría considerar aún más admirable que la del Señor dadas las dificultades de su contexto!

Antes de comparar a los jesuitas directamente con Cristo, los compara con la estrella de Cristo que guió a los Reyes Magos: el oficio de los dos es traer infieles y gentiles a la fe cristiana (Sermões 219). Sin embargo, los jesuitas exceden con su labor a la estrella bíblica porque ésta se queda con los pastores en su propia región, mientras que los jesuitas tienen que ir en busca de las ovejas para Cristo en regiones extrañas. La estrella se fue con los Magos a la tierra prometida, y los jesuitas tienen que ir a tierras remotas y peligrosas (220-1). Otra analogía entre la estrella de los Reyes Magos y los jesuitas es que ambos les

\footnotetext{
${ }^{11} \mathrm{Al}$ reflexionar sobre el origen y el significado de la palabra "barroco”, Sarduy expone además la estrecha conexión entre el pragmatismo pedagógico de los jesuitas y la forma estética del estilo barroco: "Cifrado pues, en barroco, el método, el modo, pero también la vocación primera de ese estilo, que no por azar ha podido relacionarse con la expansión jesuítica: la pedagogía, la expresión enérgica que no sólo da a ver, sino que 'pone las cosas frente a los ojos'. Arte de la argucia: su sintaxis visual está organizada en función de relaciones inéditas: distorsión e hipérbole de uno de los términos, brusca noche sobre otro; desnudez, ornamento independiente del cuerpo racional del edificio, adjetivo, adverbio que lo retuerce, voluta: todo artificio posible con tal de argumentar, de presentar autoritariamente, sin vacilaciones, sin matices. Todo por convencer" (Sarduy 1200-1). ${ }^{12}$ Baltasar Gracián escribe que "no se contenta el ingenio con sola la verdad, como el juicio, sino que aspira a la hermosura. Poco fuera en la arquitectura asegurar firmeza, si no atendiera al ornato" (Gracián 32). Pero la firmeza del efecto pragmático de Vieira se consigue precisamente manipulando el ornato ingenioso.
} 
hablan a los gentiles en su propia lengua, pues los Reyes Magos eran astrólogos. Mientras que los Magos tuvieron que estudiar la astrología para entender el mensaje de la estrella, los jesuitas han tenido que aprender y estudiar las lenguas de los indígenas para poder predicarles la fe: "Na antiga Babel houve setenta e duas linguas: na Babel do rio das Amazonas já se conhecem mais de cento e cincoenta, tão diversas entre si como a nossa e a Grega; e assim quando lá chegamos, todos nós somos mudos, e todos elles surdos” (Sermões 222). Al presentar la imagen de los indios paganos como sordos y de los misioneros como mudos, por falta de una lengua común, Vieira traza la peligrosa comparación de la obra de los jesuitas con los milagros de Jesús. Mientras que Cristo sólo tuvo que curar a un mudo y a un sordo para legitimar su causa, a los jesuitas no les basta la trabajosa labor de aprender más de ciento cincuenta lenguas nuevas para que se valore su proyecto: "De maneira que a Christo bastou-lhe fazer fallar um mudo e ouvir um surdo, para dizerem que tudo fazia bem feito; e a nós não nos basta fazer o mesmo milagre em tantos mudos, e tantos surdos, para que nos não tenham por malfeitores” (223). Por medio de atrevidas analogías y peligrosas comparaciones con la estrella de los Reyes Magos y con Cristo mismo se presenta a los jesuitas como el protagonista colectivo que trae la luz y la fe a la “obra”. Más adelante Vieira expondrá por qué también se debe añadir la protección de los indígenas a sus labores para poder sacar a las tierras nuevamente de las tinieblas.

El "villano" de la obra son los colonos. Éstos son los lobos que amenazan el rebaño de Dios. En una época en que era lugar común denominar a los indígenas de Brasil como antropófagos, Vieira invierte esta noción y propone que los caníbales en realidad son los colonos portugueses. Primero establece que los misioneros han podido transformar a los indígenas de fieras en hombres:

[...] aquellos gentios, que hoje começaram a ser homens, hontem eram feras. Eram aquelles mesmos barbaros, ou brutos, que sem uso da razão, nem sentido de humanidade, se fartavam de carne humana; que das caveiras faziam taças para lhe beber o sangue, e das canas dos ossos frautas para festejar os convites. E estas são hoje as feras que em vez de nos tirarem a vida, nos acolhem entre si, e nos veneram [...] estas as aves de rapina que em vez de nos comerem nos sustentam. (Sermões 218)

Los indios ya no se comen a los cristianos sino que los sustentan. En cambio, los colonos que esclavizan a los indígenas, diciendo que de otra manera no podrían comer, son los que destruyen el cuerpo de los indios para poder alimentarse:

Dizem que se não podem sustentar, nem o Estado se póde conservar d'outro modo. Vêde que razão esta para se ouvir com ouvidos catholicos, e para se articular e apresentar diante de um tribunal ou rei christão! Não nos podemos sustentar d'outra sorte, senão com a carne e sangue dos meseraveis Indios! Então elles são os que comem gente? (Sermões 239)

Con la imagen más dramática posible -el caníbal que se alimenta de la carne humana-Vieira les pregunta a los reyes católicos de Portugal si quieren que su Estado se fundamente en la antropofagia. 
La eficacia del discurso de Vieira proviene no sólo de sus imágenes sorprendentes y conmovedoras. En el capítulo titulado “As Quatro Fontes do Discurso Engenhoso nos Sermões do Padre Antônio Vieira”, Saraiva analiza las estrategias discursivas del jesuita a nivel de las palabras, las imágenes, las “proporciones” -término que toma de Baltasar Gracián- y del texto. Sus observaciones sobre la manera en que Vieira manipula las palabras son particularmente útiles para leer el Sermón de la Epifanía. Saraiva afirma que Vieira le da una tensión a casi cada palabra que incorpora en su texto. Cada palabra "parece ocupar el lugar que le es propio, como en estado de alerta” (Saraiva 9). Por medio de relaciones entre series de sinónimos, contraposiciones y un amplio uso de la etimología, entre otros recursos lingüísticos y retóricos, Vieira rompe el vínculo entre el significante y el significado y destruye la unidad significante (Saraiva 10-11). El resultado es la proliferación de una multiplicidad de significados provenientes de una misma palabra. Un ejemplo de este proceso en el Sermón de la Epifanía serían los juegos de palabras que usa el predicador, aprovechando el doble sentido. Cuando nos recuerda que Cristo también fue perseguido por Herodes, como los jesuitas por los colonos en Maranhão, Vieira escribe: "não debalde nos honrastes com o nome de Companhia de Jesus, obrigando-nos a vos fazer companhia no que padecestes nascido debaixo do mesmo nome” (Sermões 217). La “Compañía de Jesús” le debe hacer compañía a Jesús, al ser perseguidos como él lo fue, simplemente dado su nombre.

Otra manera en que se juega con la multiplicidad de posibles significados es el desajuste y reajuste de distintos fragmentos de palabras. Esto crea vínculos entre palabras que no necesariamente serían asociables:

O processo da “anatomía da palavra” permite, como se vê, justapor a uma parte da palavra significados que a palavra inteira não tem. É uma maneira mais ousada de quebrar a unidade significante. O que fica no lugar da palavra é um ser, se assim se pode dizer, mutável e imprevisível, sempre se metamorfoseando, se desestruturando e se reestuturando. Não apenas as partes das palavras podem ser tomadas isoladamente, mas elas mudam de lugar e de vizinhos e nos surpreendemos em reencontrá-las em contextos semânticos imprevistos, e mesmo em línguas diferentes. (Saraiva 14)

Esta estrategia de la "anatomía de la palabra” se utiliza en el Sermón de la Epifanía cuando nos habla de la corte. Juega con la idea de la luz de la estrella de los Reyes Magos $=>$ una idea lúcida $=>$ el lucirse en la corte y la oscuridad. Dice que cuando los Magos llegaron a Jerusalén, la estrella se escondió. Esta acción le parece al jesuita la "acción más lúcida” de la estrella, puesto que le parece más honorable venerar a Dios en privado, a escondidas de la corte, que venerar a Dios para lucirse enfrente de la corte (Sermões 223). Las estrellas de los jesuitas en Brasil alumbran en donde no son vistas: "no logar mais desluzido, e no canto mais escuro de todo o mundo. E é visto verdadeiramente esconderse, porque não é só desterrar-se para sempre, mas enterrar-se” (224, énfasis mío). El sonido del fonema y la palabra "luz" se vincula con la lucidez intelectual, la pretensión de lucirse ante los demás; y el opuesto binario de estos términos se manifiesta en su experiencia laudable en Brasil, el lugar más “deslucido”, más oscuro y escondido del mundo. 
La preocupación cabalística de Vieira por los fragmentos de palabras a nivel de las letras se observa cuando se refiere a las lenguas de los indígenas: ${ }^{13}$ “A lingua geral de toda aquella costa carece de tres lettras: F, L, R: De F, porque não tem fé, de L, porque não tem lei, de R, porque não tem rei” (Sermões 225). El jesuita equipara la gran ausencia que existía en la comunidad indígena antes de la llegada de los cristianos con las letras que no existían en el idioma nativo. No tenían fe, ley, ni rey, según su perspectiva, y esto se manifestaba en la falta de estos sonidos en su vocablo. Esta carencia lingüística se compara con las condiciones socio-políticas y espirituales en las que vivían los indios. ${ }^{14}$

Al desestabilizar el vínculo entre el significado y el significante, Vieira posibilita una proliferación de múltiples significados de una misma palabra. También, al asociar imágenes y conceptos dispares a través de conexiones fonéticas, etimológicas, o de otro tipo, el predicador abre la posibilidad de crear vinculaciones inusitadas: “[...] O significante, assim como o significado, só é isolado para receber novas significações ou para aproximar conceitos muito distantes” (Saraiva 61). Incluso, cuando Vieira usa la Biblia como punto de referencia, Saraiva describe que "o Livro torna-se cada uma das palavras que contém, e estas palavras são multiplicadas com a multiplicidade de sentidos. E assim até o infinito" (Saraiva 27). Sin embargo, esta multiplicación de sentidos hasta el infinito no resulta en una proliferación anárquica de significados.

Al contrario, Vieira se aprovecha de la flexibilidad que tienen las palabras y sus fragmentos desestabilizados para amoldarlos según su propósito. Vieira mantiene un firme control sobre los efectos producidos por su discurso ingenioso. La finalidad pragmática está clara. Cada palabra se subordina a la intención de convencer a los reyes de Portugal de que deben enviar a los misioneros jesuitas de vuelta a Brasil, y que deben darles jurisdicción sobre la protección de los indígenas ante los colonos.

En un análisis comparativo sobre el significado de las palabras “pastor” y “mercenario", el predicador expone su argumento principal: que los jesuitas no sólo deben convertir a los indios y cuidar de sus almas, sino que también deben proteger sus cuerpos físicos para desempeñar completamente su misión ante Dios. La diferencia que establece es que el pastor es responsable de apacentar y defender a sus ovejas mientras que el mercenario apacienta pero no defiende a sus ovejas. Los jesuitas nunca faltaron a su obligación de ser pastores a pesar de que los lobos (colonos) les disputaron el hecho de que defendieran a sus ovejas (los indígenas) contra ellos (Sermões 231-233). Al igual que San Pablo, que se representa con libro y espada, simbolizando su responsabilidad de enseñar y defender, los jesuitas necesitan tener acceso a la "espada” porque si no su labor de catequismo será en vano. Los colonos “quieren que a los ministros del Evangelio pertenezca sólo la cura de las almas, y que el cautiverio de los cuerpos sea de los ministros del Estado" (Sermões 229). Pero esta distribución de poder no tiene sentido para el jesuita, según lo ilustra con la imagen de las llaves de San Pedro a las puertas del cielo.

Primero explica el predicador que hay dos caminos por los que Portugal lleva el cristianismo a sus conquistas: uno para traerles la fe a los paganos; el otro para librarlos de la tiranía, “un camino para salvarles las almas, otro para librarles los cuerpos” (228).

Ainda que um d'estes caminhos pareça só espiritual, e o outro temporal, ambos pertenecem á Igreja e ás chaves de S. Pedro, porque por um abrem-se as portas do céo, 
e por outro fecham-se as do inferno [...] Não sei se reparaes em que deu Christo a S. Pedro não só chave, senão chaves: Tibi dabo claves. Para abrir as portas do céo, bastava uma só chave: pois por que lhe dá Christo duas? [...] porque umas são as portas do céo, e outras as portas do inferno [...] Por isso é necessario que as chaves sejam duas, e que ambas estejam na mesma mão [...] uma com que possa levar os gentios a Christo, e outra com que os possa defender do demonio, e seus ministros. E toda a teima do mesmo demonio, e do mesmo inferno, é que estas chaves e estes poderes se dividam, e que estejam em differentes mãos. (Sermões 229, énfasis mío)

Cristo le dio dos llaves a San Pedro porque no basta con abrir la puerta del cielo, también hay que asegurarse de que esté cerrada la puerta del infierno. En la opinión de Vieira estas dos llaves deben estar en una misma mano. Si se dividen los poderes que conllevan las dos llaves se puede filtrar el demonio. Las mismas personas encargadas de llevarles la fe a los gentiles -los jesuitas- deben poder ejercer en contra del demonio: los colonos corruptos, que quieren amenazar a los indios con la esclavitud.

En lugar de pedirle a los reyes que castiguen a los colonos que se han propasado al expulsar a los jesuitas, Vieira declara que su propósito es el de sugerir un "remedio" para mejorar la empresa colonial en Brasil. Sus sugerencias son tres: Primero, que "aquellas tierras sean pobladas con gente de mejores costumbres y verdaderamente cristiana”, puesto que les sirven de ejemplo a los indios (241). Los que se han mandado hasta la fecha han sido criminales y malhechores, y esto refleja mal en la república que representan. Segundo, "que las congregaciones eclesiásticas de aquel estado estén compuestas por sujetos que sepan decir la verdad y que la quieran decir” (242). Él mismo ha sabido decir la verdad, y está en el transcurso de decirla en su sermón, aunque sabe que algunas de las personas oyéndolo preferirían que no la dijera. Tercero, “que todos [los remedios] que sean necesarios para la buena administración y cultura de aquellas almas, se les deben no sólo conceder, mas aplicar efectivamente, sin que los mismos gentiles, o nuevos cristianos (ni otros por ellos) lo pidan o busquen” (247). Los tres “remedios” delatan las animosidades y la fricción entre el padre Vieira y sus múltiples enemigos: los colonos y los otros religiosos. A pesar de ser un sermón que se supone que comunique un ejemplo universal de buen comportamiento, o por lo menos que trace una recomendación política para los reyes de acuerdo a la perspectiva de la Iglesia, "el Texto lo comenta [y lo delata] a él” con todas sus particularidades de individuo controversial.

La eficacia del pragmatismo de Vieira se deriva en gran parte del espectáculo que elabora con la ingeniosidad de su discurso, de lo llamativo y asombroso de su retórica y del carisma de su performance. El efecto de sus imágenes sorprendentes es comparable al que describe Stephen Gilman en "An Introduction to the Ideology of the Baroque in Spain”, con la idea de capturar y mantener la atención del público "shocking him into awareness" [sorprendiéndolo para concientizarlo] (Gilman 96). Al interesar a sus oyentes y capturar su imaginación con imágenes de antropofagia y de las llaves de la puerta del infierno, Vieira puede adoctrinarlos y convencerlos de su mensaje. La necesidad de recurrir al texto del Evangelio lo lleva a crear imágenes distorsionadas que revelan la tensión entre la Biblia y la realidad histórica que le toca vivir. Así, los Reyes Magos se convierten en los reyes de Portugal, la estrella de Cristo se equipara con los jesuitas, y los 
jesuitas hasta asumen la posición de Cristo mismo en un momento culminante del sermón, reproduciendo los milagros de éste, pero siendo injustamente castigados y calumniados como malhechores. Si bien el sermón en Portugal incorpora la función social del teatro secular español, según lo propone Vieira Mendes, la manipulación psicológica que se lleva a cabo en el sermón está ligada mucho más estrechamente a la implementación de la política imperial. En el caso de este sermón en particular, el predicador tiene la oportunidad expresa de afectar esta política ya que su público incluye a los reyes mismos. Con el Sermón de la Epifanía Vieira se abre un espacio para la intervención directa en la estructuración de la jerarquía de poder en la colonia de Brasil.

BiBLIOGRAFÍA

Almansur Haddad, Jamil. Sermões. São Paulo: Companhia Editora Nacional, 1957.

Cohen, Thomas M. The Fire of the Tongues: António Vieira and the Missionary Church in Brazil and Portugal. Stanford: Stanford University Press, 1998.

D’Azevedo, J. Lucio. Historia de Antonio Vieira. Lisboa: Livraria Clássica Editora, 1918. Fernandes Brandão, Ambrósio. Diálogos das Grandezas do Brasil. Recife: Imprensa Universitária, 1962.

Gilman, Stephen. “An Introduction to the Ideology of the Baroque in Spain”. Symposium $1,1946$.

Gracián, Baltasar. Agudeza y Arte de Ingenio. México: UNAM, 1996.

Hallyn, Fernand. The Poetic Structure of the World: Copernicus and Kepler. New York: Zone Books, 1990.

Maravall, José Antonio. La cultura del barroco. Barcelona: Editorial Ariel, 1975.

O’Malley, John W. The First Jesuits. [1993] Cambridge and London: Harvard University Press, 1998.

Palacin, Luís. Vieira e a visão trágica do barroco. São Paulo: Editora Hucitec, 1986.

Peloso, Silvano. "Ut libri prophetici melius intelligantur, omnium temporum historia complectenda est: o Quinto Império de António Vieira e o debate europeu nos séculos XVI e XVII”. Vieira escritor. Margarida Vieira Mendes, Maria Lucília Gonçalves Pires y José da Costa Miranda, ed. Lisboa: Edições Cosmos, 1997. 17787.

Rabassa, Gregory. "Vieira in the Maranhão: Out of Pragmatism, Prophecy”. Colonial Latin American Review I/1-2 (1992).

Saraiva, Antonio J. O Discurso Engenhoso: Estudos sobre Vieira e outros autores barrocos. São Paulo: Editora Perspectiva, 1980.

Sarduy, Severo. “Barroco”. Obra completa, edición crítica. Gustavo Guerrero y François Wahl, coordinadores. Tomo II. Colección Archivos. Madrid: ALLCA XX, 1999. 1195-262.

Vieira Mendes, Margarida. A oratória barroca de Vieira. Lisboa: Editorial Caminho, 1989. 